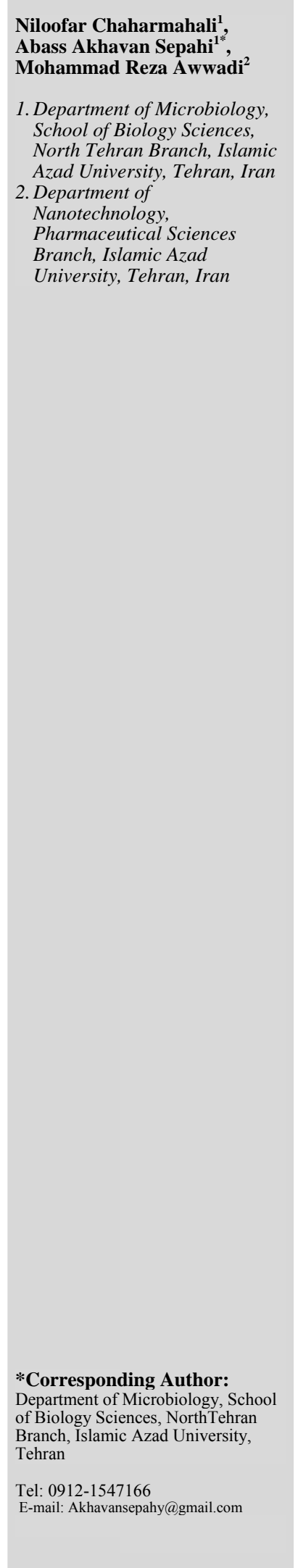

\title{
Comparison of the Native Bacillus subtillis and Bacillus Megaterium Strains Isolated from Soil in Production of Riboflavin
}

\section{Abstract}

Background and Objectives: Vitamin B2 (riboflavin) is a water-soluble vitamin and yellow. The aim of this study is to identify strains of Bacillus isolated from soil do with the ability to produce riboflavin by PCR.

Materials and Methods: Soil samples was mild randomly during 2 consecutive days the air. Sampling was performed of areas far from the sun and from 3 to $10 \mathrm{~cm}$ soil depth. The genus Bacillus were identified to species level using standard methods. Also isolates were approved identified using the PCR method. To study the riboflavin production of synthetic culture media were used and HPLC techniques.

Result: PCR using gene 16SrRNA test results showed that 32 strains obtained from a strain of Bacillus subtilis and 10 were 2 strain of Bacillus megaterium. The isolated strains of Bacillus megaterium PTCC 1250 with standard strains were positive of riboflavin production in synthetic medium and HPLC.

Conclusions: Bacillus subtilis bacteria living in the soil among the most important role in the production of riboflavin and riboflavin-producing strains to confirm the use of molecular methods is necessary.

Keywords: Bacillus species, Riboflavin, 16SrRNA 


\section{مقايسه سويههاى بومى باسيلوس سوبتيليس و باسيلوس مكاتريوم جداشده از خاك در توليد ويتامين ريبوفلاوين}

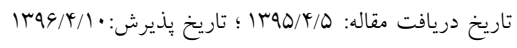

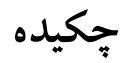

زمينه و هدف: ويتامين B (ريبوفلاوين) يك ويتامين زردرنگ و محلـول در آب مسىباشــ. هــف از انجـام ايسن مطالعـه شناسايى سويههاى باسيلوس جداشده از خاك با توانايى در توليد ريبوفلاوين با روش PCR مىباشد.

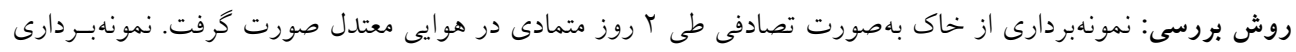

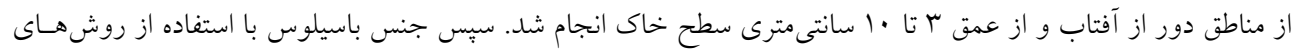

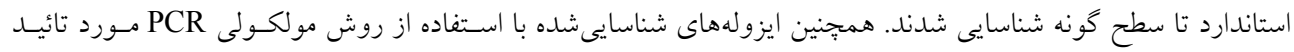
قرار گرفتند. جهت بررسى توليد ريبوفلاوين از محيط كشت سنتيكى و تكنيك HPLC استفاده خرديد.

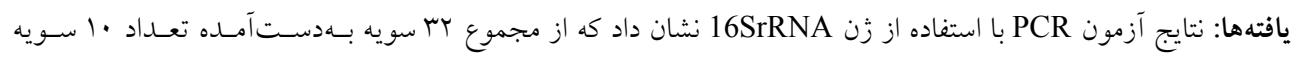
باسيلوس سوبتيليس و r سويه باسيلوس مخاتريوم بودند. اين سويههاى جداسازى شده به همراه سويه استاندارد باسيلوس مكاتريوم PTCC 1250 ازنظر توليد ريبوفلاوين در محيط كشت سنتيكى و HPLC مثبت بودند. نتيجه گيرى: در ميان باكترىهاى ساكن خاك باسيلوس سوبتيليس بيشترين نقـش را در ميـزان توليـــ ريبـوفلاوين داشـته و

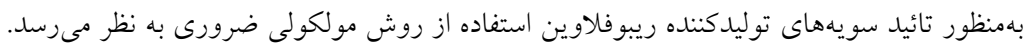
كلمات كليدى: كونههاى باسيلوس، ريبوفلاوين، 16SrRNA

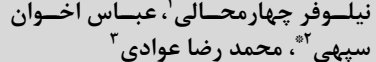

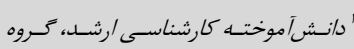

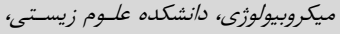
دانشَاه آزاد /سلامى واحد تهران شمال،

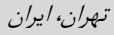
كانشيار، كـروه ميكروبيولـوزي، دانشكانده

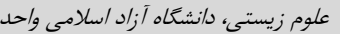

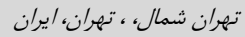

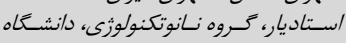
آزاد /سلامى واحد علوم دارويى، تهران، ايران 
مى كنند، استفاده مى شود. ' جنس باسـيلوس شـامل بـاكترىهـيى

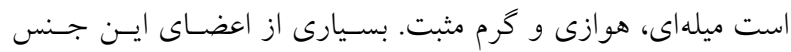
بهصورت سايروفيت در خاك، آب، هوا و سبزىها ديده مى شـوند و ورئ از ميكروار كانيسمهاى توليدكننده ويتامين B2 (ريبوفلاوين) هستـند.

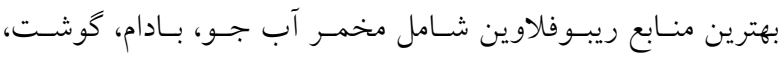

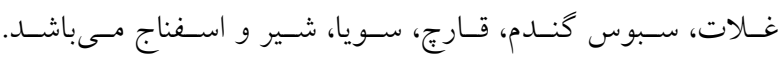
ريبوفلاوين در اثر نور و قليا نظير جوش شيرين از بين مى رود. براى

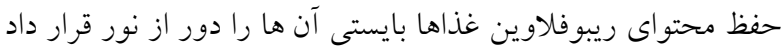
ريبو فلاوين عمدتاً بهوسيله آسكوميست هاى رشتهاى توليد مى شوند

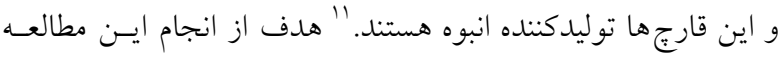

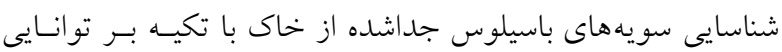
آنها در توليد ريبوفلاوين به كمك روش PCR مىباشد.

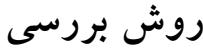

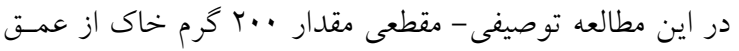

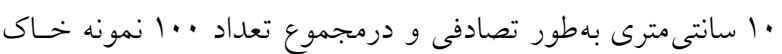

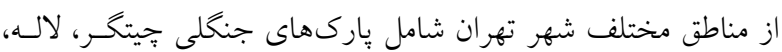
ملت و يرديسان و از مكـانهـاى دور از نـور خورشـيد در شـرايط

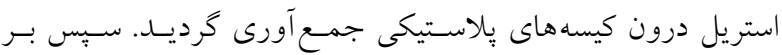
اساس بروتوكل تائيد شده توسط WHO، ه گرم از خاك را در فويل

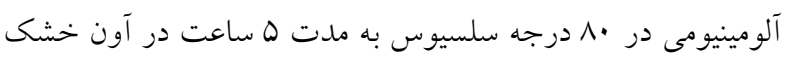

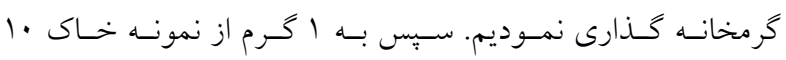
ميلى ليتر سرم نمكى (W/V85\%) اضـافه نمــوده و ورتكـس شــــ

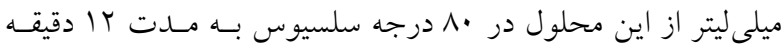

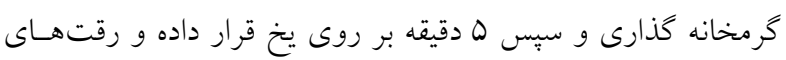

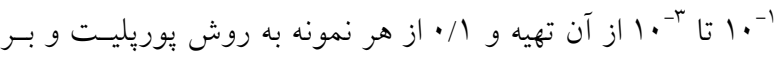
روى محيط لوريا آكار (شركت مرى كشور آلمان) كشت داده و بعد بهد

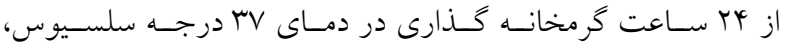
كلنىهاى مشكوى به باسيلوس جداسازى و ايزولههـا ازنظـر تسـت

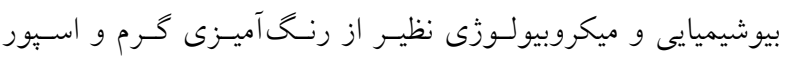

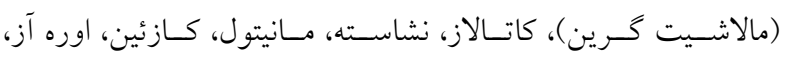
سيترات، MRVP و زلاتيناز استفاده شد. باسيلوس مخاتريوم PTCC 1250 تهيه شده از سازمان علمى و يزووهشى صنعتى ايران، بـهنعــوان
ويتامينهـا گروهـى از مـواد شـيميايى هسـتند كـه فراينـدهاى فيزيولوزيك را كنترل كرده و بر روى آنها تأثير گذارند، ضمن اينكه

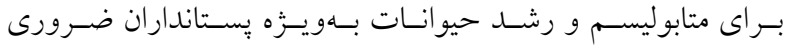

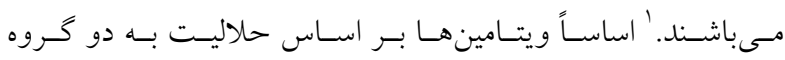
و يتامينهاى محلول در جربى (A, D, E K) و ويتامينهـاى محلـول در آب شامل B B (سيانوكوبالامين)، B B (اسيد فوليك)، B (بيـوتين)،

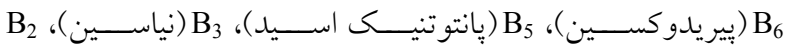
(ريبـوفلاوين)، B B (تيـامين) و C (اسـيد آسـكوربيك) مسى باشـند. ريبوفلاوين با فرمول شيميايى C17H20N4O6 و نام لورى دى متيـل

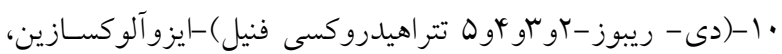
زردرنگ و با حلاليت پِيين در آب شناخته مىشود. ' ايسن ويتـامين بهوسيله ميكروار گانيسمها سنتز مى شود ولى مهرهداران توانايى سنتز

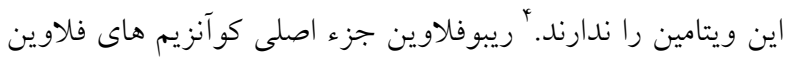

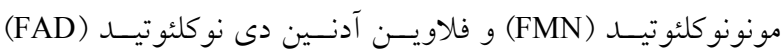
مىباشد. هر دو كوآنزيم واكنش هاى اكسيداسيون- احياء غير آنزيمى

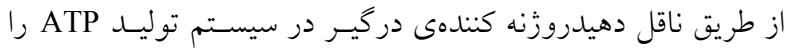

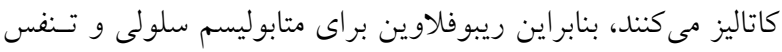

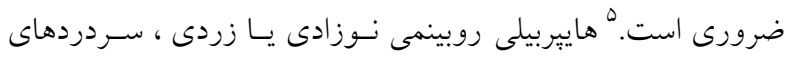

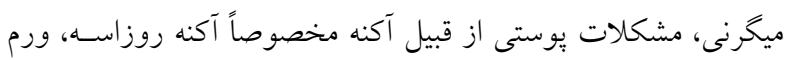

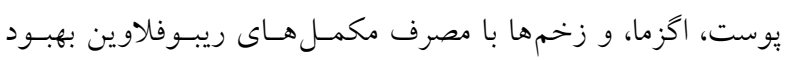

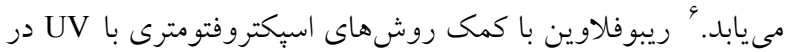

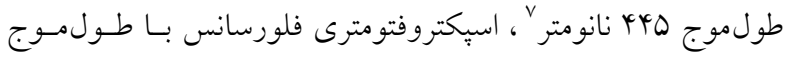

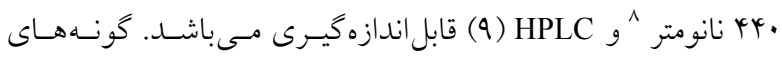

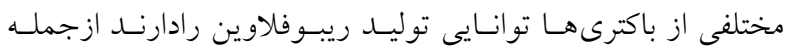

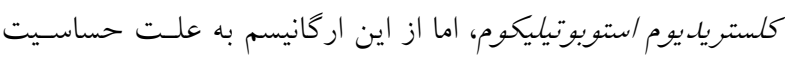

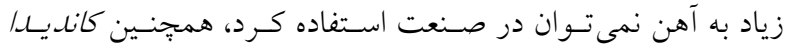
ريبوفلاوين كه به ميزان mg/1 · .9 ريبوفلاوين توليد مى كند اما ايسن

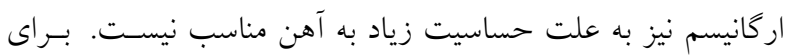
رسـيدن بـه توليــ ريبـوفلاوين در Bacillus subtilis سـتنز يـورين

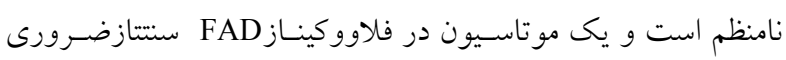
است. يك آنالوى ساختمانى ريبوفلاوين، رزوفلاوين براى گـزينش Bacillus subtilis 


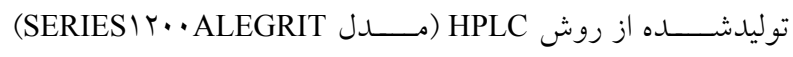

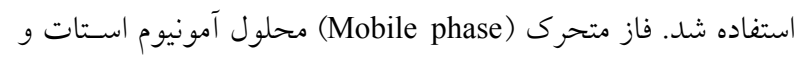

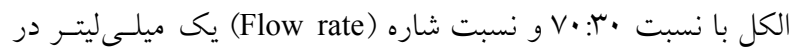
دقيقه بود. زمان بازدارندكى (Retention time) 9-ه دقيقـه محاسـبه كرديد. ب' درنهايت دادها با Anova Test بررسى و تجزيسهو تحليـل كرديد.

\section{يافته ها}

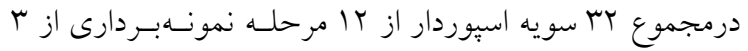

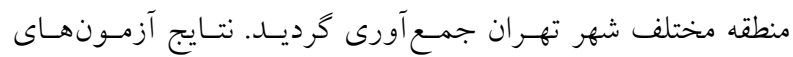

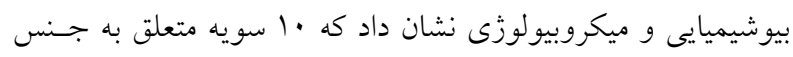
باسـيلوس سـوبتيليس و r سـويه نيـز متعلسق بـه جـنس باسـيلوس

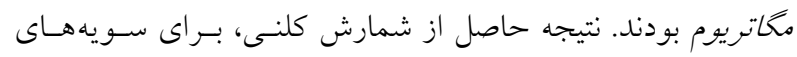

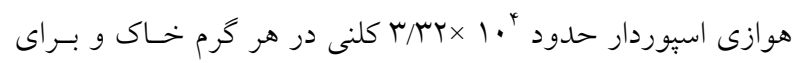

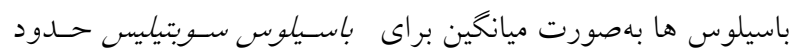

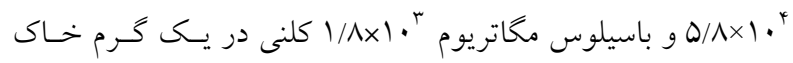
بود. نمودار حاصل از HPLC براى تشخيص ريبـوفلاوين نشـان داد كه زمان بازدارنـدكى (Retention Time) ريبـوفلاوين اسـتاندارد در محدوده 9-ه دقيقه و سطح زير نمودار نمايانحر غلظت آن مىباشد.

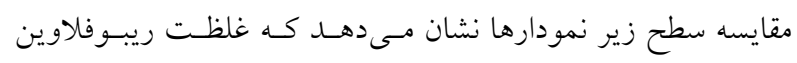

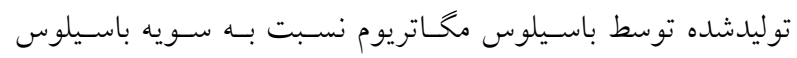

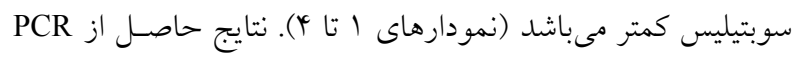
و الكتروفورز زن هدف براى تائيسد سـويه باسـيلوس سـوبتيليس در شكل ا نشان دادهشده است. جهت تعيين توالى محصـول PCR بـهـ شركت آرمين شخرف فرستاده شد.نتيجه تعيين توالى را با استفاده از روش بلاست كـردن و مقايسـه بـا تـوالى هـاى قطعـه تكثيــ يافتـه 16SrRNA بهطور غالب Bacillus subtilis مسىباشــ (شـكل Y). ميـزان تشـابه

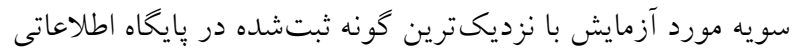
Eztaxon نتايج سويه بررسى شده مربوط به شاخه باكتريايى Firmicutes، رده

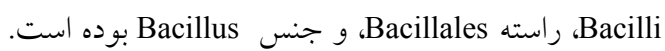

سويه استاندارد مورداستفاده قرار كرفت. بهمنظور شناسايى مولكولى سويههـاى توليدكنتــــ ريبـوفلاوين،

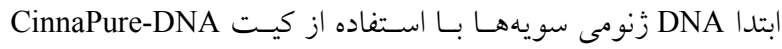
(Cell culture, Tissues, Gram Positive Bacteria and CSF)

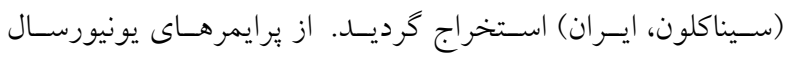
موركان جهت تكثير زن \$ 19 rRNA با توالىهـاى معلـوم و شـامل

$\mathrm{R}=5^{\prime}-\mathrm{F}=5^{\prime}-$ CCAGCAGCCGCGGTAATACG-3' Tر ســويه هــاى باسـيلوس استفاده شد كه طول قطعه حاصل از تكثير YA bp بود. جهت تائيـد

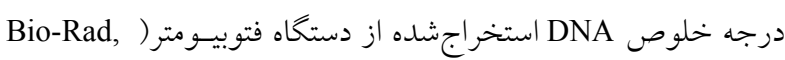

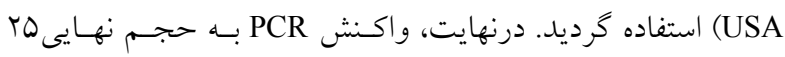
ميكرو ليتر شامل ه/ه ميكرو ليتر PCR master mix 5X (سـيناكلون، ايـران) حساوى (Taq DNA polymerase (0.05

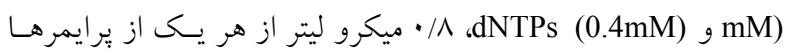

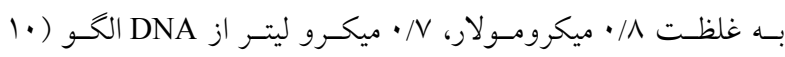
نانو گرم) و \& أ ميكرو ليتر آب ديونيزه استريل با استفاده از گراديانت ترموسايكلر(ايندورف، آلمان) براى هـ سيكل بهصورت زيــر انجـام كرفت: مرحله واسرشتخى در دماى ه9 درجه سلسيوس به مــدت 1

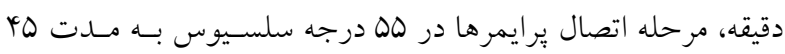
ثانيه و مرحله طويل سازى در VY درجه سلسيوس به مد مدت فه ثانيه.

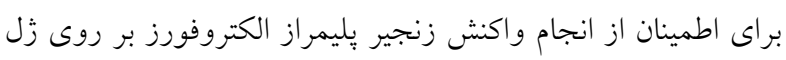

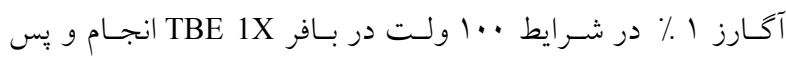

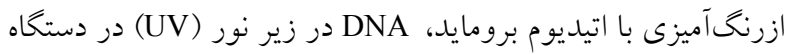
Gel doc محيط كشت اختصاصى جهت توليد ريبوفلاوين با اين تركيبات

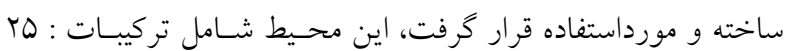

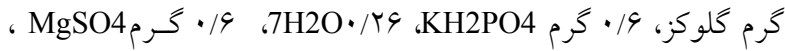

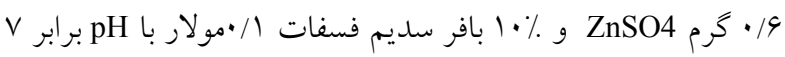

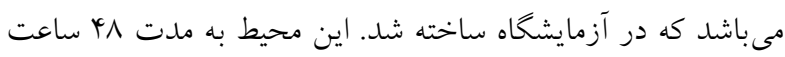

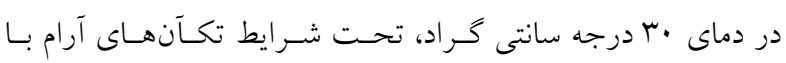
سرعت rpm · · ادر شرايط هوازى قرار داده شد. توليد ريبـوفلاوين در محيط كشت براث بعد از ^^^ ساعت مورد ارزيابى قـرار گرفـت. جهت جلو كيرى از اكسيداسيون ريبوفلاوين محسيطهـاى كثـت در

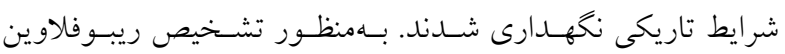




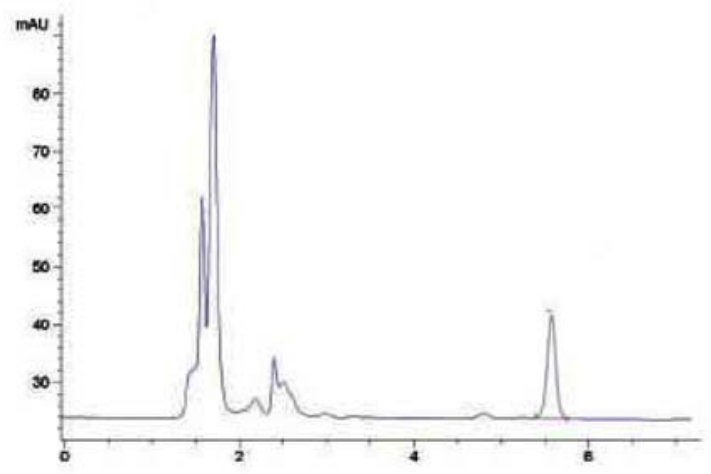

نمودار ا: كروماتوكراف نمونه استاندارد ريبوفلاوين به روش HPLC (محور افقى ميزان توليد ريبوفلاوين و محور عمودى رقـت مـوردنظر توليــ ريبوفلاوين)

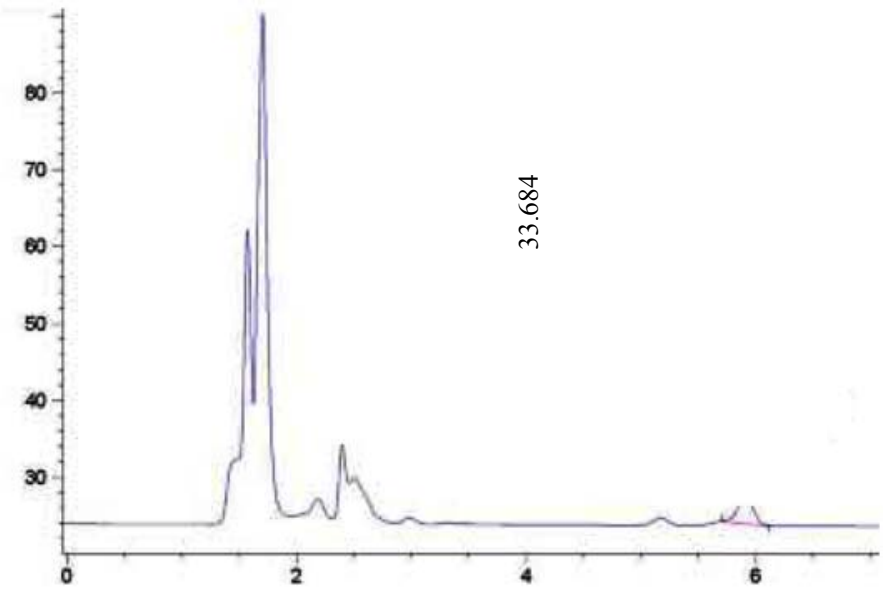

نمودار Y: توليد ريبوفلاوين توسط سويه PTCC 1250 Bacillus megaterium (محور افقى ميـزان توليــ ريبـوفلاوين و محسور عمـودى رقـت موردنظر توليد ريبوفلاوين)

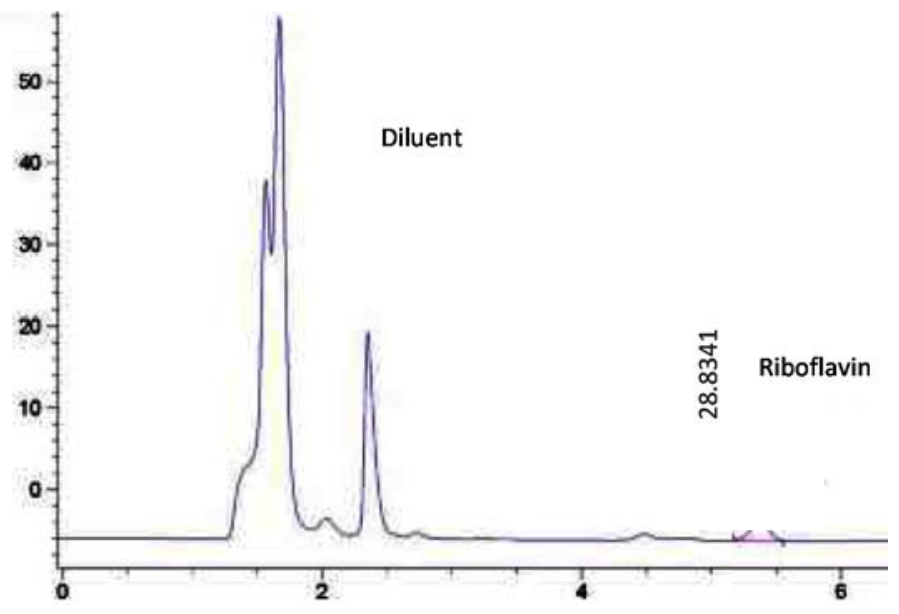

نمودار ب: توليد ريبوفلاوين توسط سويه Bacillus megaterium جداشده از خاك يارك جنخلى جيتخر (محور افقى ميـزان توليــ ريبـوفلاوين و محور عمودى رقت موردنظر توليد ريبوفلاوين) 


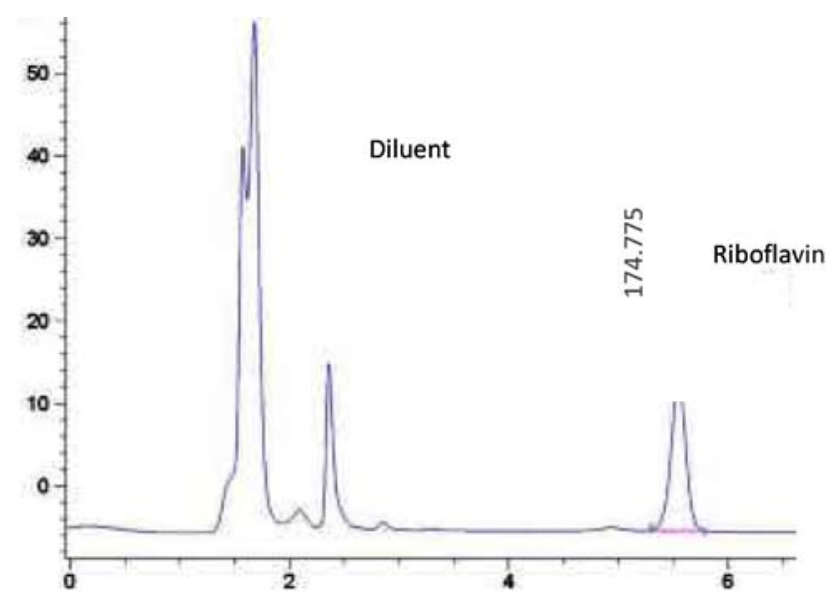

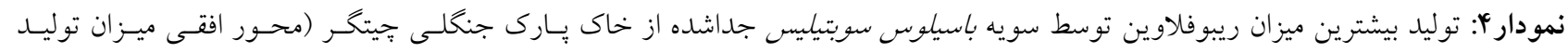
ريبوفلاوين و محور عمودى رقت موردنظر توليد ريبوفلاوين)

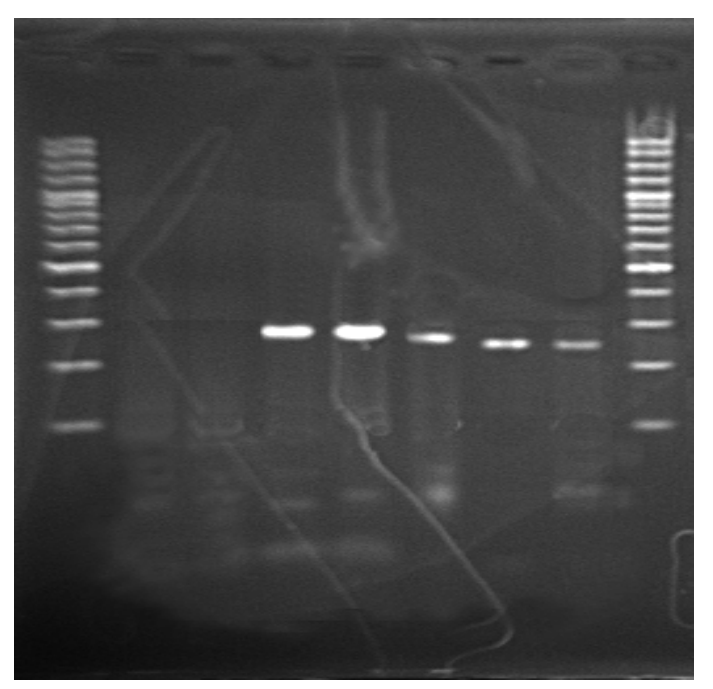

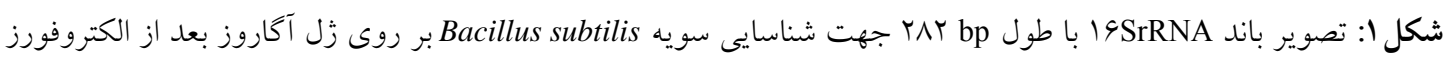

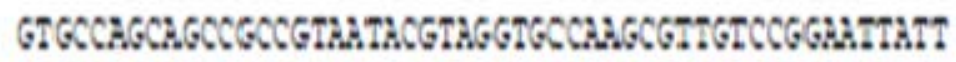

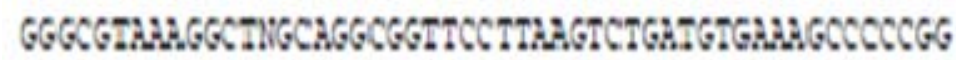

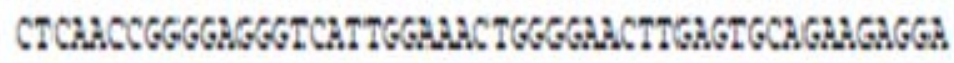

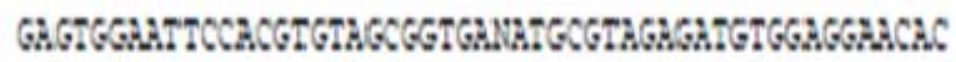

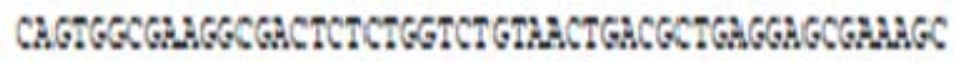

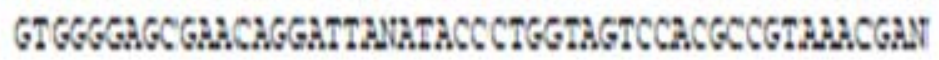

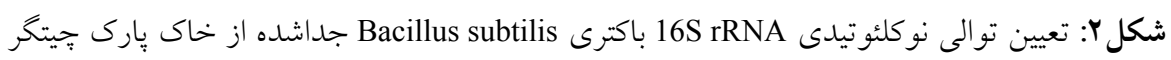


ستتيكى مىتواند بر روى توليد ريبـوفلاوين تأثيركـــار باشـــ. دليـل

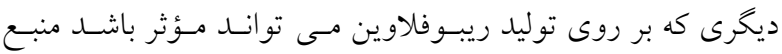

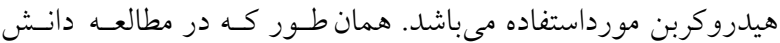

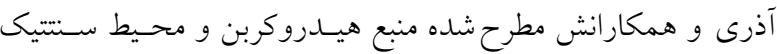

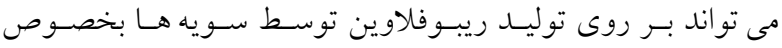

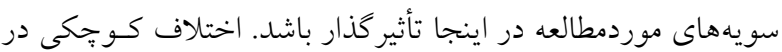
ميـزان توليــد ريبـوفلاوين در بـين باسـيلوس سـوبتيليس هــاى

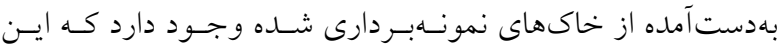

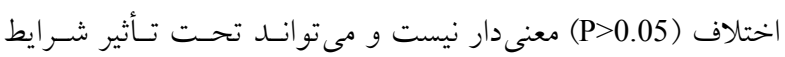

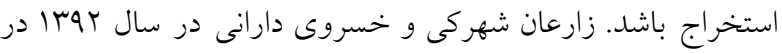

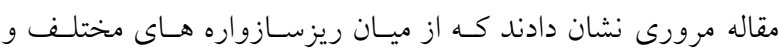

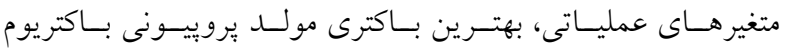

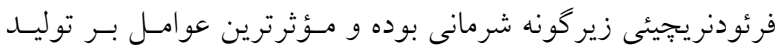

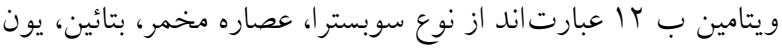
كبالت، هو 9 دى متيل بنزيميدازول، pH و دما. به نظر مى رسد آينده

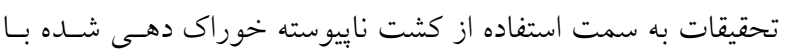

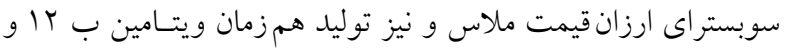
اسيديروييونيك در نوشيدنى هاى تخميرى صـورت قِــيرد. بـا ايسن فين

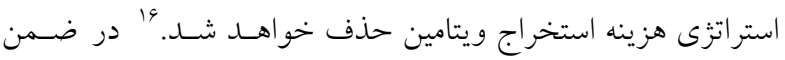

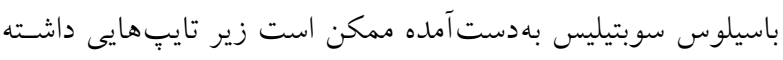

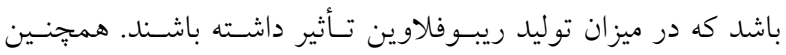
بامطالعه مقالات مختلف مشخصشده است كـه Retention Time براى ريبوفلاوين بر اساس جنس فاز متحرى و ستون مورداستفاده متفاوت مى باشد. درروش كار مطالعه حاضـر از سـتون 18C و فــاز

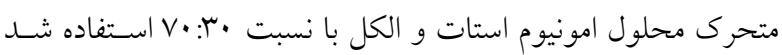
و هetention time ها و د دقيقه به دست آمد.

\section{نتيجه گيرى}

بر اساس يافتهاى بهدست آمده، باسـيلوس سـوبتيليس سـرعت

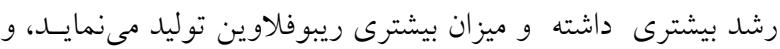

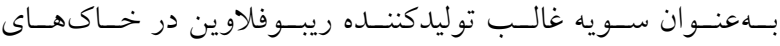

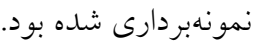

در اين مطالعه جنس غالب در مناطق نمونسهـبـردارى باسـيلوس سـوبتيليس بــود. در صـنعت بــراى توليســ انبـوه ريبـوفلاوين از اركانيسمهـاى زيـادى ازجملـه؛ Ashbya gossypii كانديـا فاماتـا، مخمرها و باسيلوس سوبتيليس استفاده مىشود. "ا ميزان ريبـوفلاوين

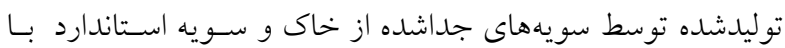
روش HPLC سنجيده شد. براى اطمينان از صسحت عملكـرد روش طراحسى شـــه، تكراريــــيرى نتـايج و CV كــار بــا اسـتفاده از

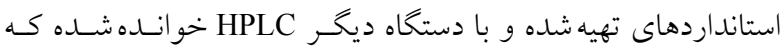

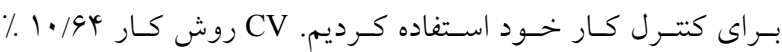

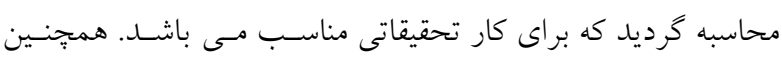
بامطالعه مقالات مختلف مشخص شــده اسـت كـه Retention Time براى ريبوفلاوين بر اساس جنس فاز متحرى و ستون مورداسـتفاده متفاوت مى باشد. در روش كار مطالعه حاضـر از سـتون Cl\ و فـاز

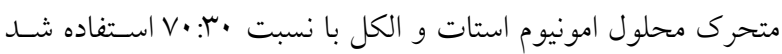
و Retention time ه تا و دقيقه به دست آمد. نتـايج نشـان داد كـه ميزان توليـــ ريبـوفلاوين در بـين سـويههـاى باسـيلوس مخـاتريوم (اسـتاندارد و بـومى) و باسـيلوس سـوبتيليس اخـتلاف معنسىدارى وجود دارد بدين معنسى كـه بـاوجود مهيـا بـودن شـرايط توليد، توانايى باسيلوس سوبتيليس در توليــ ريبـوفلاوين بيشـتر از

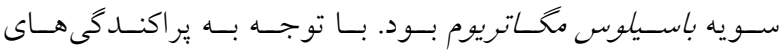
نمونهبردارى و سويههاى بهدستآمده مى توان اينــور عنـوان كـرد كه سـويه غالـب جـــس باسـيلوس در منـاطق نمونسه بـردارى شـــه Bacillus subtilis

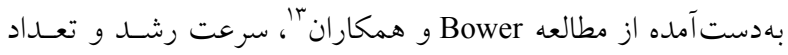
اويرون مىتواند دليلى بر توليد بيشتر ريبوفلاوين توسـط باسـيلوس

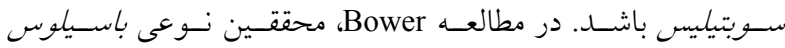
سوبتيليس را طراحسى نمودنــد كـه حساوى جنـــين كيسى از إيـرون بيوسنتيك ريبوفلاوين(ايرون rib) بود. لذا سرعت سنتز ريبوفلاوين در اين سويه سنتزى طراحى شده در مقايسه با سـويه تيـِّ وحشى

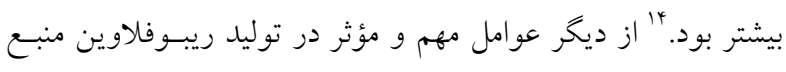

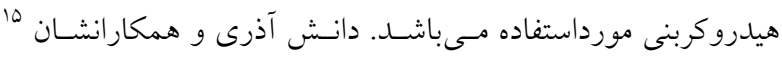
نشان دادند كه منبع هيدروكربن و تركيبات موجـود در محسيطهـاى نوري 


\section{ملاحظات اخلاقى}

كليـه اقــدامات جهـت رعايـت اخــلاق در تهيـهـ و اسـتفاده از

اطلاعات مقالات ديخر جهت به كار خيرى در بزوهش فعلى توسط ريط

نويسند كان اتخاذ گرديد. اين مقاله كد اخلاقى ندارد.

\section{References}

1. Clarke M, Ward M, Strain JJ, Hoey L, Dickey W, McNulty H. B-vitamins and bone in health and disease: The current evidence. Proc Nutr Soc. 2014; 73: 330-339.

2. Van Meurs JBJ, Dhonukshe-Rutten RAM, Pluijm SMF, van der Klift M, de Jonge R, Lindemans J. Homocysteine levels and the risk of osteoporotic fracture. N Engl J Med. 2004; 350: 2033-2041.

3. De Groot CP. Vitamin B 12, folate, homocysteine, and bone health in adults and elderly people: a systematic review with meta-analyses. J Nutr Metab. 2013; 486:186.

4. Matte JJ, Guay F, Girard CL. Bioavailability of vitamin B 12 in cows' milk. British J Nutr. 2012; 14;107(01):61-6.

5. Carmel R, Green R, Rosenblatt DS, Watkins D. Update on cobalamin, folate, and homocysteine. ASH Education Program Book. 2003(1):62-81.

6. Kanis JA, Johnell O. Requirements for DXA for the management of osteoporosis in Europe. Osteoporosis Int. $2005 ; 16(3): 229-38$.

7. Zatalia SR, Sanusi H. The role of antioxidants in the pathophysiology, complications and management of diabetes mellitus. Acta Med Indones. 2013; 45(2); 141147.

8. Brun PJ, Yang KJ, Lee SA, Yuen JJ, Blaner WS. Retinoids: Potent regulators of metabolism. Biofactors. 2013; 39(2): 151-163.

9. Raghow, R. Metabolic balancing acts of vitamin A in type-2 diabetes and obesity. World J Diabetes. 2012;

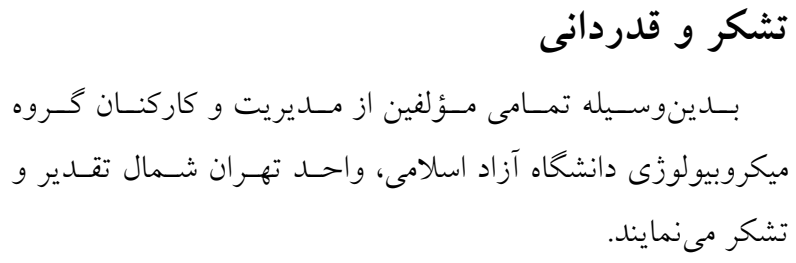

3(10): 174-177.

10. Polidori MC, Mecocci P, Stahl W, Parente B, Cecchetti R, Cherubini A, et al. Plasma levels of lipophilic antioxidants in very old patients with type 2 diabetes. Diabetes Metab. Res Rev., 2000; 16(1): 15-19.

11. Macdonald HM, McGuigan FE, Fraser WD, Ralston SA, Reid SH. Methylene tetrahydrofolate reductase polymorphism interacts with riboflavin intake to influence bone mineral density. Bone. 2004; 35: 957-964.

12. Fratoni V, Brandi ML. B Vitamins, Homocysteine and Bone Health. Nutrients. 2015; 7: 2176-2192.

13. Bower S, Perkins J, Yocum RR, Serror P, Sorokin A, Rahaim P, et al. 1995. Cloning and characterization of the Bacillus subtilis birA gene encoding a repressor of the biotin operon. J Bacteriol. 1995; 177:2572-75.

14. Perkins JB, Pero J. Vitamin biosynthesis. In Bacillus subtilis and Its Closest Relatives. American Society of Microbiology 2002 : 271-286.

15. Daneshazari R, Roayaei M, Najafzadeh H. Isolation and identification of a riboflavin producer yeast from Nectarine. Biol J Microorganism. 2014 ;3(10):27-36.

16. Shahraki Z, Khosravi Darani S, Khosravi Darani K. effective factor on microbial production of vitamin B12. 21 st science \& food industry international congress. Shiraz. Shiraz university. $2013 \quad$ http://www. civilica. com /Paper-NCFOODI21-NCFOODI21_1145.html. 